\title{
HOST COLONIZATION DIFFERENCES BETWEEN CITRUS AND COFFEE ISOLATES OF Xylella fastidiosa IN RECIPROCAL INOCULATION
}

\author{
Simone de Souza Prado; João Roberto Spotti Lopes²*; Clarice Garcia Borges Demétrio; \\ Adriano Ferreti Borgatto ${ }^{4}$; Rodrigo Piacentini Paes de Almeida ${ }^{5}$ \\ ${ }^{1}$ USP/ESALQ - Programa de Pós-Graduação em Entomologia Agrícola. \\ ${ }^{2}$ USP/ESALQ - Depto. de Entomologia, Fitopatologia e Zoologia Agrícola - C.P. 09 - 13418-900 - Piracicaba, SP - \\ Brasil. \\ ${ }^{3}$ USP/ESALQ - Depto. de Ciências Exatas - C.P. 09 - 13418-900 - Piracicaba, SP - Brasil. \\ ${ }^{4}$ UFSC/CTC/INE - Depto. de Informática e Estatística - C.P. 476 - 88040-900 - Florianópolis, SC - Brasil. \\ ${ }^{5}$ UCB - Dept. of Environmental Science, Policy and Management - 137 Mulford Hall - Berkeley, CA - 94720-3114 - \\ USA. \\ *Corresponding author <jlopes@esalq.usp.br>
}

\begin{abstract}
Citrus variegated chlorosis (CVC) and coffee stem atrophy (CSA) are important diseases in Brazil associated with closely-related strains of Xylella fastidiosa, but little is know about host overlapping and importance of citrus and coffee as inoculum sources of these strains. In this study, reciprocal-inoculation experiments were performed to determine if CVC and CSA isolates are biologically similar within citrus and coffee plants. These two hosts were mechanically inoculated with a CVC and a CSA isolate of $X$. fastidiosa at four concentrations ranging between $10^{3}$ and $10^{9}$ colony forming units CFU mL $\mathrm{m}^{-1}$. At two, four and eight months after inoculation, the infection efficiency and bacterial populations of the isolates in each host were determined by culturing. The CVC isolate infected both citrus and coffee plants, but developed lower populations in coffee. The CSA isolate did not colonize citrus. Inoculation of coffee plants with the CVC isolate resulted in low rates of infection and required an inoculum concentration ten-fold higher than that necessary to obtain a similar (25\%) rate of infection in citrus. The relatively low infection rates and bacterial numbers of the CVC isolate in coffee plants compared with those observed in citrus suggest that coffee is not a suitable host to serve as a source of inoculum of the CVC strain for primary spread to citrus or within coffee plantations.

Key words: citrus variegated chlorosis, coffee leaf scorch, inoculum concentration, bacterial population, epidemiology
\end{abstract}

\section{DIFERENÇAS EM COLONIZAÇÃO DO HOSPEDEIRO POR ISOLADOS DE Xylella fastidiosa DE CITROS E CAFEEIRO EM INOCULAÇÕES RECÍPROCAS}

\begin{abstract}
RESUMO: Clorose variegada dos citros (CVC) e atrofia dos ramos do cafeeiro (ARC) são doenças importantes no Brasil, associadas a estirpes de Xylella fastidiosa que são geneticamente próximas. Entretanto, pouco se sabe a respeito de plantas hospedeiras em comum e da importância de citros e cafeeiro como fontes de inóculo dessas estirpes. Neste estudo, realizaram-se experimentos de inoculação recíproca para determinar se isolados de $X$. fastidiosa de CVC e de ARC são biologicamente semelhantes em plantas de citros e café. Estes dois hospedeiros foram mecanicamente inoculados com um isolado de CVC e um isolado de ARC, em quatro concentrações que variaram de $10^{3}$ a $10^{9}$ unidades formadoras de colônias UFC $\mathrm{mL}^{-1}$. Aos dois, quatro e oito meses após a inoculação, a eficiência de infecção e a população bacteriana dos isolados em cada hospedeiro foram determinadas por cultura. O isolado de CVC infectou tanto plantas de citros quanto de café, mas desenvolveu populações mais baixas em cafeeiro. O isolado de ARC não colonizou citros. A inoculação de plantas de café com o isolado de CVC resultou em baixas taxas de infecção e exigiu uma concentração de inóculo dez vezes mais alta que a necessária para obter uma taxa de infecção semelhante (25\%) em citros. A reduzida taxa de infecção e a baixa população bacteriana do isolado de CVC em cafeeiro em relação a citros sugerem que cafeeiro não é um hospedeiro adequado para atuar como fonte de inóculo da estirpe de CVC para disseminação deste patógeno para pomares de laranja ou dentro de cafezais. Palavras-chave: clorose variegada do citros, requeima das folhas do cafeeiro, concentração de inóculo, população bacteriana, epidemiologia
\end{abstract}




\section{INTRODUCTION}

Two plant diseases caused by the bacterium Xylella fastidiosa, citrus variegated chlorosis (CVC) and coffee stem atrophy (CSA) emerged in São Paulo State, Brazil, in 1987 and 1995, respectively, suggesting that they were caused by the same pathogen strain (Paradela Filho et al., 1997). Yet, genetic studies have shown that $X$. fastidiosa isolates from citrus and coffee cluster separately from each other although they form a monophyletic group (Costa et al., 2000; Qin et al., 2001; Martinati et al., 2005). Interestingly, Li et al. (2001) were able to infect coffee plants and observe CSA-like symptoms after inoculation with an isolate originally from citrus, suggesting the possibility of cross-infection by these strains. Li et al. (2002) also showed that both CVC and CSA isolates can cause symptoms of Pierce's Disease in grapevine. In addition, Lopes et al. (2003) demonstrated that CVC and CSA isolates had similar colonization patterns in various weed host plants. Thus, it is important to understand the host range of proposed $X$. fastidiosa isolates through biological assays.

We compared host colonization by $X$. fastidiosa CVC and CSA isolates in reciprocal-inoculation experiments given that previous reports suggested genetic differences, but potential biological host range overlapping between isolates from citrus and coffee (Costa et al., 2000; Li et al., 2001; Martinati et al., 2005). The importance of inoculum concentration for mechanical inoculation of this bacterium was also studied. Although mechanical inoculation of $X$. fastidiosa is widely used for pathogenicity and functional genomics research, the importance of inoculum concentration has never been systematically addressed for this pathogen in reciprocal-inoculation studies.

\section{MATERIAL AND METHODS}

Test plants - Coffee seedlings (Coffea arabica L., cv Catuaí vermelho/clone 99) and citrus seedlings [Citrus sinensis (L.) Osbeck, cv. Caipira] were grown in one liter plastic bags containing a mixture of soil, manure and sand (3:2:1). Plants were always kept in an insect proof greenhouse. One month before inoculations, citrus seedlings were pruned at $10 \mathrm{~cm}$ above soil surface and fertilized with a NPK + Ca, S, Mg and $\mathrm{Zn}$ - fertilizer, in order to induce formation of a young flush in each plant. Two months after inoculation plants were transplanted to four liters plastic bags containing the same substrate mixture and fertilized with nitrogen. Test plants had $\sim 25 \mathrm{~cm}$ in height when inoculated.
$X$. fastidiosa isolates - Two isolates were used, one from a citrus plant with CVC symptoms in Bebedouro (205' S; 48 $28^{\circ}$ 'W), São Paulo State (CCT6570; Tropical Culture Collection, Campinas, Brazil) and another from a coffee plant with CSA in Matão (21 ${ }^{\circ} 36^{\text {' }}$ S; 48²6’ W), São Paulo (CCT6756). After primary isolation from the field the isolates were triply cloned on periwinkle gelrite (PWG). Eight-day old colonies were suspended and stored at $-80^{\circ} \mathrm{C}$ in a succinate phosphate citrate buffer with glycerol $(30 \% \mathrm{v} / \mathrm{v})$. Before inoculations, the isolates were grown on PWG medium for two passages. Bacteria were always cultured on PWG medium and their populations within plants were quantified by calculating the average number of CFU 14 days after plating (Hill \& Purcell, 1995; Almeida et al., 2001). Colonies of both isolates were routinely examined by PCR to confirm the bacteria's identity (Minsavage et al., 1994).

Inhibition test of $X$. fastidiosa growth by ground coffee tissue - Ground plant material may release plant inhibitors that affect $X$. fastidiosa growth in vitro (Purcell \& Saunders, 1999), although such inhibition was not observed in the presence of citrus homogenates (Almeida et al., 2001). Here we compared five treatments to verify any possible in vitro inhibition on growth of the CSA isolate by coffee tissue (petioles) using two different methods of maceration: a) $X$. fastidiosa cell suspension macerated in a mortar with $0.01 \mathrm{~g}$ of healthy coffee tissue; b) cell suspension homogenized in a tissue grinder $(20,000 \mathrm{rpm} / 15 \mathrm{~s})$ with $0.01 \mathrm{~g}$ of healthy coffee tissue; c) cell suspension without coffee tissue neither homogenized nor macerated; d) cell suspension macerated without coffee tissue; and e) cell suspension homogenized without coffee tissue. A $X$. fastidiosa suspension with $\sim 10^{8}$ CFU mL ${ }^{-1}$ of phosphate buffered saline (PBS) was used. A drop of $20 \mu \mathrm{L}$ was added to vials for homogenization or mortars with $1.8 \mathrm{~mL}$ of sterile PBS in all treatments, and processed as above. Suspensions were diluted 10- and 100-fold and plated onto PWG. All treatments were replicated four times. Data were transformed to $\mathrm{Log}$ CFU g ${ }^{-1}$ of tissue and analyzed using ANOVA and Tukey test $(P<0.05)$.

Inoculation of CVC isolate in citrus and coffee plants - Test seedlings of both hosts were mechanically inoculated with $5 \mu \mathrm{L}$ of a concentrated suspension $\left(10^{9} \mathrm{CFU} \mathrm{mL}{ }^{-1}\right)$ of the CVC isolate using the pinpricking method (Almeida et al., 2001). Each seedling was inoculated in a single point of the stem, located 1 $\mathrm{cm}$ below the first pair of fully developed leaves. Plants were kept without irrigation for one day before inoculation, so that suspension drops were quickly absorbed (1-3 min). Three replications of 15 citrus and coffee 
plants were inoculated with the bacterial suspension in January, 2002. The negative control consisted of 15 plants from each host inoculated with PBS. The proportion of infected plants was determined by culture and PCR, and the bacterial populations by culture four months after inoculation. Bacterial DNA extraction from inoculated plants was done according to Minsavage et al. (1994), except for a change in ascorbic acid concentration (0.1 M) and extract dilution (1:100) (Pinto \& Leite Junior, 1999). PCR was carried out with conditions and primers specific for detection of citrus and coffee isolates of $X$. fastidiosa (Pooler \& Hartung, 1995; Coletta Filho et al., 2001). The proportion of infected plants was compared using the test of difference among two proportions (Magalhães \& Lima, 2002). ANOVA and the Tukey test $(P<0.05)$ were used to compare bacterial populations in both hosts.

\section{Reciprocal-inoculation of CVC and CSA isolates}

- Citrus and coffee seedlings were mechanically inoculated with four cell concentrations of each isolate, ranging between $10^{3}$ and $10^{9} \mathrm{CFU} \mathrm{mL}{ }^{-1}$, as described above. Cell suspensions of the CVC isolate, which were inoculated in February/2002 had $3.2 \times$ $10^{8}, 6.2 \times 10^{7}, 3.0 \times 10^{5}$ and $5.0 \times 10^{3} \mathrm{CFU} \mathrm{mL}^{-1}$, as quantified by dilution plating on PWG. Cell suspensions of the CSA isolate, inoculated in March/2002 had $3.0 \times 10^{9}, 9.5 \times 10^{7}, 7.5 \times 10^{6}$ and $1.5 \times 10^{4}$ $\mathrm{CFU} \mathrm{mL}{ }^{-1}$. Both experiments were set up using a completely randomized factorial design with eight treatments ( 2 hosts, $1 \mathrm{X}$. fastidiosa isolate, 4 bacterial concentrations), which were replicated three times with 15 test plants each. In total, each isolate was inoculated in 180 plants of each host, whereas 20 plants of each host were inoculated only with PBS to serve as negative controls. We sampled fully matured leaves on the upper portion of each test plant at two, four and eight months after inoculation to determine the percentage of infected plants and bacterial populations by culturing. The presence of typical CVC and CSA symptoms on test plants was monthly recorded up to eight months.

Effective dose analysis was applied to study the relationship between inoculum concentration and cumulative proportion of infected plants at eight months after inoculation. The random variable $Y_{i}$ denotes the number of infected plants in $m_{i}$ inoculated plants, with observations $y_{i}$ and $y_{i} / m_{i}$ representing the proportion of infected plants, $i=1,2, \mathrm{~K}, n$, where $n$ is the total number of observations in the experiment. The natural choice for modelling proportion data is the binomial regression model, a case of the generalized linear models (GLM) (Collet, 2002). Assuming that $Y_{i} \sim$ Bin $\left(m_{i}, \pi_{i}\right)$ with mean $\mu_{i}=\mathrm{E}\left(Y_{i}\right)=m_{i} \pi_{i}$ and variance $\operatorname{Var}\left(Y_{i}\right)$ $=m_{i} \pi_{i}\left(1-\pi_{i}\right)$, GLM allows us to model the expected proportions $\pi_{i}$ in terms of explanatory variables $x_{i}$ (effects of treatments and covariates) through $g\left(\pi_{i}\right)=\boldsymbol{x}_{i}^{\prime} \boldsymbol{\beta}$, where $g$ is a suitable link function (logit, probit or complementary log-log) and $\beta$ is a vector of $p$ unknown parameters. To incorporate the correlation caused by the observations over time we used the generalized estimation equation methodology. A logistic model, $g\left(\pi_{i}\right)=\eta_{i}=\log \left(\pi_{i} / 1-\pi_{i}\right)$, considering doses, host plants (coffee and citrus) and time as explanatory variables was adjusted to the proportion data. The goodness of fit of the models was measured by analysis of deviance (a generalization of ANOVA) as proposed by McCullagh \& Nelder (1989). Overdispersion was assumed when the observed variance was greater than the theoretical variance specified by the model (Hinde \& Demetrio, 1998). Overdispersion was modeled by replacing the variance function of the original model by the more general form $\operatorname{Var}\left(Y_{i}\right)=\phi m_{i} \pi_{i}\left(1-\pi_{i}\right)$ and using a quasi-likelihood method for estimating the parameters.

The effective doses were calculated by $E D_{p}=1 / \hat{\beta}_{1}\left\{\ln [p /(1-p)]-\hat{\beta}_{0}\right\}$ where $p=0.05 ; 0.20$; $0.25 ; 0.50, \hat{\beta}_{0}$ and $\hat{\beta}_{1}$ are the regression coefficients. The confidence intervals for the effective doses were calculated using Fieller's method (Collet, 2002). The logarithm of bacterial population for CVC and CSA isolates was analyzed using normal distribution and according to a $2 \times 2 \times 3$ ( 2 host plants, 2 inoculum doses and 3 times after inoculation) factorial completely randomized experiment. The difference between the factors and its interactions was verified using the F test.

\section{RESULTS}

Effect of coffee macerates on in vitro growth of $X$. fastidiosa - Bacterial populations recovered by dilution plating after maceration ( $\log 6.02 \pm 0.04)$ or homogenization ( $\left.\log 5.81 \pm 0.15 \mathrm{CFU} \mathrm{mL} \mathrm{m}^{-1}\right)$ of $X$. fastidiosa cell suspension with coffee tissue were larger than those obtained with macerated (Log 5.02 \pm 0.24 ) or homogenized $\left(\log 4.72 \pm 0.22 \mathrm{CFU} \mathrm{mL}^{-1}\right.$ ) bacterial suspensions without addition of plant tissue ( $\mathrm{F}=7.21 ; P=0.002$ by ANOVA) (Table 1 ). Bacterial recovery with or without addition of coffee tissue was not significantly influenced by the two grinding methods tested. The culturing method based on homogenization of infected plant tissue in PBS and subsequent dilution plating onto solid PWG medium (Sands et al., 1988) was found to be suitable for primary isolation and quantification of $X$. fastidiosa in coffee plants. 
Table 1 - Xylella fastidiosa populations and proportions of infected citrus and coffee plants detected by culturing at 2, 4 and 8 months after inoculation with the CVC and CSA isolates.

\begin{tabular}{|c|c|c|c|c|c|c|c|c|}
\hline \multirow[t]{2}{*}{ Isolate } & \multirow{2}{*}{$\begin{array}{l}\text { Host } \\
\text { Plant }\end{array}$} & \multirow{2}{*}{$\begin{array}{l}\text { Inoculum } \\
\text { Concentration } \\
\left(\mathrm{CFU} \mathrm{mL} \mathrm{mL}^{-1}\right)\end{array}$} & \multicolumn{3}{|c|}{$\begin{array}{c}\text { Mean bacterial population Log CFU g }{ }^{-1} \\
\text { of tissue } \pm \text { SEM }\end{array}$} & \multicolumn{3}{|c|}{$\begin{array}{c}\text { Number of infected plants/total } \\
\text { inoculated }(\%)\end{array}$} \\
\hline & & & 2 months & 4 months & 8 months & 2 months & 4 months & 8 months \\
\hline \multirow{8}{*}{$\mathrm{CVC}$} & \multirow{4}{*}{ citrus } & $10^{8}$ & $5.36 \pm 0.1 \mathrm{a}^{\mathrm{y}}$ & $5.50 \pm 0.2 \mathrm{a}$ & $4.77 \pm 0.1 \mathrm{a}$ & $23 / 45(51.1)$ & $26 / 44(59.1)$ & $21 / 43(48.8)$ \\
\hline & & $10^{7}$ & $4.98 \pm 0.1 \mathrm{a}$ & $5.14 \pm 0.3 \mathrm{a}$ & $4.54 \pm 0.2 \mathrm{a}$ & $11 / 42(26.2)$ & $3 / 41(7.3)$ & $5 / 44(11.4)$ \\
\hline & & $10^{5}$ & 0 & 0 & 0 & $0 / 42(0)$ & $0 / 45(0)$ & $0 / 44(0)$ \\
\hline & & $10^{3}$ & 0 & 0 & 0 & $0 / 40(0)$ & $0 / 45(0)$ & $0 / 45(0)$ \\
\hline & \multirow{4}{*}{ coffee } & $10^{8}$ & $4.51 \pm 0.2 \mathrm{a}$ & $4.89 \pm 0.2 \mathrm{a}$ & $4.59 \pm 0.4 \mathrm{a}$ & $8 / 35(22.9)$ & $4 / 45(8.9)$ & $3 / 44(6.8)$ \\
\hline & & $10^{7}$ & 4.00 & 0 & 0 & $1 / 29(3.4)$ & $0 / 42(0)$ & $0 / 44(0)$ \\
\hline & & $10^{5}$ & 0 & 0 & 0 & $0 / 34(0)$ & $0 / 44(0)$ & $0 / 41(0)$ \\
\hline & & $10^{3}$ & 0 & 0 & 0 & $0 / 34(0)$ & $0 / 40(0)$ & $0 / 45(0)$ \\
\hline \multirow{8}{*}{ CSA } & \multirow{4}{*}{ coffee } & $10^{9}$ & $5.25 \pm 0.2 \mathrm{a}^{\mathrm{y}}$ & $5.86 \pm 0.1 b$ & $5.01 \pm 0.2 \mathrm{a}$ & $10 / 45(22.2)$ & $26 / 43(60.5)$ & $13 / 38(34.2)$ \\
\hline & & $10^{7}$ & $5.56 \pm 0.3 \mathrm{a}$ & $5.99 \pm 0.1 \mathrm{a}$ & $5.37 \pm 0.2 \mathrm{a}$ & $7 / 45(15.5)$ & $18 / 38(47.4)$ & $13 / 42(30.9)$ \\
\hline & & $10^{6}$ & $4.66 \pm 0.2 \mathrm{a}$ & $5.63 \pm 0.2 a$ & $5.58 \pm 0.1 \mathrm{a}$ & $4 / 45(8.8)$ & $5 / 38(13.2)$ & $6 / 40(15)$ \\
\hline & & $10^{4}$ & 0 & 0 & 0 & $0 / 45(0)$ & $0 / 34(0)$ & $0 / 43(0)$ \\
\hline & \multirow{4}{*}{ citrus } & $10^{9}$ & 0 & 0 & 0 & $0 / 45(0)$ & $0 / 45(0)$ & $0 / 37(0)$ \\
\hline & & $10^{7}$ & 0 & 0 & 0 & $0 / 45(0)$ & $0 / 43(0)$ & $0 / 44(0)$ \\
\hline & & $10^{6}$ & 0 & 0 & 0 & $0 / 45(0)$ & $0 / 43(0)$ & $0 / 42(0)$ \\
\hline & & $10^{4}$ & 0 & 0 & 0 & $0 / 45(0)$ & $0 / 45(0)$ & $0 / 44(0)$ \\
\hline
\end{tabular}

${ }^{\mathrm{x}}$ Same isolate concentrations were used to inoculate both host plants in each experiment. ${ }^{\mathrm{y}}$ Means followed by the same letter in same row are not different by Tukey $(P<0.05)$. Zeros were eliminated from statistical analysis.

Inoculation of CVC isolate in citrus and coffee Four months after inoculation of the CVC isolate in citrus and coffee plants, more citrus plants were positive by culturing $(73.3 \%)$ than in coffee $(22.2 \%)$ $(\mathrm{Z}=4.87 ; \mathrm{P}<0.01)$. The average bacterial population was ten times larger in citrus ( $\log 6.25 \pm 0.1$ ) than in coffee ( $\left.\log 5.32 \pm 0.2 \mathrm{CFU} \mathrm{mL}^{-1}\right)(\mathrm{Z}=4.87$; $P=0.01$, by ANOVA). Typical CVC symptoms (chlorotic spots on leaves) were observed in most citrus plants that were shown to be infected; in contrast all infected coffee plants were symptomless.

Reciprocal-inoculation of CVC and CSA isolates and effective-dose analysis - $X$. fastidiosa was never recovered by culture or PCR from citrus plants inoculated with the CSA isolate, despite the wide range of concentrations tested $\left(10^{4}\right.$ to $\left.10^{9} \mathrm{CFU} \mathrm{mL}^{-1}\right)$ (Table 1$)$. Plants of each host inoculated only with PBS (negative controls) were all negative for $X$. fastidiosa by culturing and PCR. Bacterial suspensions with $10^{5}$ and $10^{3}$ $\mathrm{CFU} \mathrm{mL}{ }^{-1}$ for CVC isolate and $10^{4} \mathrm{CFU} \mathrm{mL}^{-1}$ for the CSA isolate also did not result in any infection on either host plant. This was not surprising because relatively low numbers of cells (5 to 500) were likely present per 5$\mu \mathrm{L}$ drop of the $10^{3}, 10^{4}$ and $10^{5} \mathrm{CFU} \mathrm{mL} \mathrm{m}^{-1}$ suspensions that were inoculated in each plant. Thus, the results herein presented do not consider these lower inoculum concentrations for the statistical analyses performed.
Fitting the logistic model to the proportion data gave residual deviances of 29.95 and 35.32 on 26 and 18 degrees of freedom, respectively, for CVC and CSA, showing evidence of overdispersion in the second case (Hinde \& Demetrio, 1998). It was found evidence of 'host plant' and 'dose' effect, but not of 'time' effect. The adjusted curves for the cumulative proportion of infected plants obtained were (Figure 1):

CVC/Coffee: $\ln \left[\hat{p}_{i} /\left(1-\hat{p}_{i}\right)\right]=35.3125+1.7572 \ln$ (dose); CVC/Citrus: $\ln \left[\hat{p}_{i} /\left(1-\hat{p}_{i}\right)\right]=24.3598+1.3643 \ln ($ dose $)$; and

CSA/Coffee: $\ln \left[\hat{p}_{i} /\left(1-\hat{p}_{i}\right)\right]=-8.8423+0.4964 \ln ($ dose $)$.

The CVC isolate infected more citrus than coffee plants ( $P=0.0028)$, and its highest inoculum concentration $\left(10^{8} \mathrm{CFU} \mathrm{mL} \mathrm{mL}^{-1}\right)$ resulted in a higher infection rate in both hosts $(P=0.0057)$. Likewise, there was a trend of higher proportions of infected coffee plants by the CSA at higher inoculum concentrations, although the effect of dose was not statistically significant in this case $(P=0.1183)$. CVC symptoms were observed only in plants infected with the CVC isolate in the two highest inoculum concentrations $\left(10^{7}\right.$ and $10^{8} \mathrm{CFU} \mathrm{mL} \mathrm{m}^{-1}$ ). CSA symptoms were not observed in any treatment during the evaluation period of eight months; some typical symptoms e.g. shortening of in- 
ternodes, leaf size reduction and yellowing were observed only two years later in infected test plants that remained in the greenhouse.

The effects of time period after inoculation on the infection rate by CVC $(P=0.1455)$ and CSA $(P=0.0605)$ isolates were not significant, but a tendency of higher proportions of infected plants at four months post-inoculation was observed for the homologous isolate/host combinations (CVC/citrus and CSA/ coffee) (Table 1). However, in the case of the CVC isolate in coffee (heterologous host), the highest proportion of infected plants was registered two months after inoculation, declining afterwards. The adjusted curves using the cumulative data by culturing after eight months showed that the bacterial dose of the CSA isolate for infecting at least $5 \%$ of the coffee plants $\left(\mathrm{ED}_{5}\right)$ is lower $\left(\approx 10^{5} \mathrm{CFU} \mathrm{mL}{ }^{-1}\right)$ than that required by the CVC isolate for infection of citrus $\left(\approx 10^{6} \mathrm{CFU} \mathrm{mL}\right.$ ${ }^{1}$ ) and coffee plants $\left(\approx 10^{8} \mathrm{CFU} \mathrm{mL}^{-1}\right)$ (Table 2). Confidence intervals for higher effective doses $\left(\mathrm{ED}_{20}\right.$ and $\mathrm{ED}_{25}$ ) were shorter, providing a higher degree of confidence (Figure 2). Confidence intervals showed that the CVC isolate in citrus requires lower inoculum doses than in coffee to infect 20 or $25 \%$ of plants. CSA isolate requires the lowest bacterium concentrations to infect coffee plants; an inoculum concentration (6.0

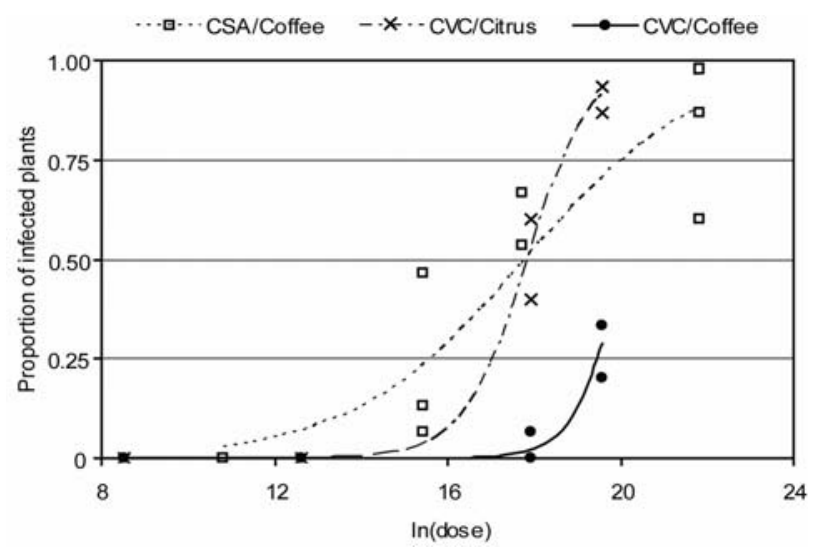

Figure 1 - Modeled adjusted curves and observed values relating inoculum concentration $[\ln ($ dose $)]$ and cumulative proportion of infected plants 8 months after inoculation with Xylella fastidiosa isolates (CVC and CSA) in coffee and citrus. Curves were based on a logistic model. $\times 10^{6} \mathrm{CFU} \mathrm{mL} \mathrm{mL}^{-1}$ ) around 50 times lower than that of the CVC isolate $\left(2.9 \times 10^{8} \mathrm{CFU} \mathrm{mL}^{-1}\right)$ is necessary to infect 25\% coffee plants (Table 2). In the homologous hosts, however, similar doses $\left(\approx 10^{7}\right.$ or $\left.\ln 18 \mathrm{CFU} \mathrm{mL}^{-1}\right)$ are needed to promote $50 \%$ infection by the two isolates (Figure 1, Table 2).

The bacterial population of the CVC isolate in infected plants was statistically similar between the two hosts (citrus and coffee) and doses $\left(10^{7}\right.$ and $10^{8} \mathrm{CFU}$ $\mathrm{mL}^{-1}$ ) compared, as well as among the different time periods (2, 4 and 8 months) after inoculation (Table $1)$. The analysis of variance showed that there was no evidence of any effect and interactions $(P>0.05)$ for CVC isolate. For the CSA isolate there was evidence for the effect of time, but not of dose. The bacterial population of the CSA was higher at four months after inoculation, but did not vary among the doses compared.

\section{DISCUSSION}

The analyses of infection rates, effective doses and bacterial populations in citrus and coffee plants carried out in these reciprocal-inoculation experiments indicate that these CVC and CSA isolates of $X$. fastidiosa are biologically different. The tested CVC

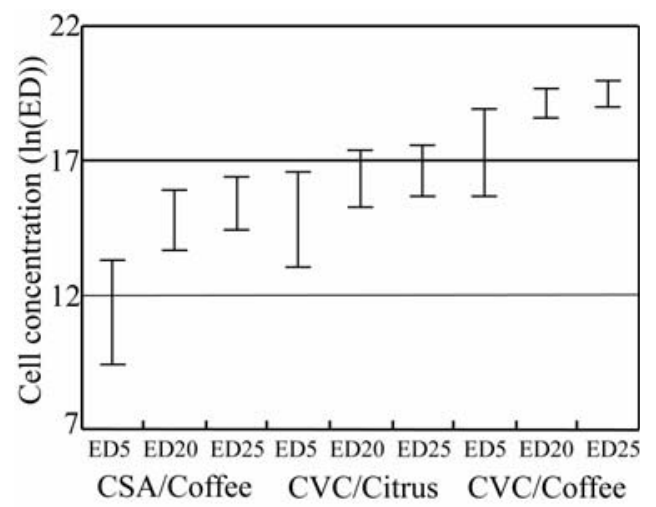

Figure 2 - Confidence intervals comparing effective doses [ln(ED)] required to infect 5, 20 and $25 \%$ of plants for each isolate/host plant combination based on cumulative data of 8 months after inoculation. Intervals illustrate the range of bacterial concentrations required to mechanically infected test plants.

Table 2 - Effective inoculum doses (in CFU mL $\mathrm{mL}^{-1}$ ) for infection rates of 5, 20, 25 and 50\% in coffee and citrus plants by two Xylella fastidiosa isolates.

\begin{tabular}{lcccc}
\hline Isolate/host plant & $\mathrm{ED}_{5}$ & $\mathrm{ED}_{20}$ & $\mathrm{ED}_{25}$ & $\mathrm{ED}_{50}$ \\
\hline $\mathrm{CSA} /$ coffee & $1.5 \times 10^{5}(11.9)^{\mathrm{a}}$ & $3.3 \times 10^{6}(15.0)$ & $6.0 \times 10^{6}(15.6)$ & $5.4 \times 10^{7}(17.8)$ \\
$\mathrm{CVC} /$ citrus & $6.6 \times 10^{6}(15.7)$ & $2.0 \times 10^{7}(16.8)$ & $2.7 \times 10^{7}(17.1)$ & $5.9 \times 10^{7}(17.9)$ \\
$\mathrm{CVC} /$ coffee & $1.0 \times 10^{8}(18.4)$ & $2.4 \times 10^{8}(19.3)$ & $2.9 \times 10^{8}(19.5)$ & $-\mathrm{b}$ \\
\hline
\end{tabular}

${ }^{a}$ Values within parentheses represent the logarithm (ln) of the effective doses (ED), which were estimated by using cumulative data of 8 months after inoculation and the equations given by the logistic model. ${ }^{\circ} \mathrm{ED}_{50}$ was not estimated for the CVC isolate in coffee because $50 \%$ infection is above the range of observed infection rates for this isolate/host combination. 
isolate colonizes both citrus and coffee plants, whereas the CSA isolate colonizes coffee but does not colonize citrus. Li et al. (2001) had previously shown that a CVC isolate causes disease in coffee, but the CSAcitrus combination had not been tested before. There is a dose-effect on inoculation efficiency of these isolates in both hosts. The CVC isolate required higher doses to infect coffee than citrus, suggesting that the ability of this isolate to colonize coffee plants is reduced in comparison with citrus. Similar inoculum concentrations of the CSA isolate resulted in higher infection efficiency than the CVC isolate in coffee.

While the proportion of the plants detected as infected increased up to four months following inoculation in the homologous isolate/host combinations (CVC/citrus and CSA/coffee), the rate of coffee plants infected by the CVC isolate declined after two months post-inoculation. Interestingly, no infections by the CVC isolate were detected in coffee plants 12 months

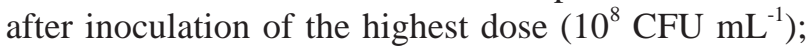
in contrast, $72 \%$ of citrus plants inoculated with the same suspension were $X$. fastidiosa positive after 12 months (data not shown). This observation suggests that coffee is not a long term host for the CVC strain of $X$. fastidiosa.

The results of this study differ substantially from those of Li et al. (2001), who observed leaf scorch symptoms and detected $X$. fastidiosa by PCR in a high proportion of coffee plants (seven out of ten) inoculated with a CVC isolate, eight months after inoculation. The higher proportion of coffee plants infected by the CVC isolate in their study might be due to the inoculation method, which involved introduction of much larger volumes of bacterial suspensions per plant compared with the pin-pricking method that we used. They injected each plant 20 times with a $10^{8}$ to $10^{9} \mathrm{CFU} \mathrm{mL}^{-1}$ suspension, by using a large gauge (22 g) needle attached to a syringe, whereas we inoculated test plants with only $5 \mu \mathrm{L}$ of cell suspensions in a single point of the stem. Sands et al. (1988) and Schaad et al. (2004) have suggested that natural methods of inoculation and relatively low inoculum concentrations $\left(10^{3}\right.$ to $\left.10^{5} \mathrm{CFU} \mathrm{mL} \mathrm{mL}^{-1}\right)$ should be used in reciprocal-inoculation studies of broad host pathogens such as Pseudomonas syringae pv. syringae and $X$. fastidiosa, in order to avoid reactions on non-hosts that may be misinterpreted as a true pathogenic response. Another source of difference may lay on the detection protocols used. We relied on culturing as a detection method, which unlike PCR detects only viable cells.

Mechanical inoculation of $X$. fastidiosa is widely used for various studies with this pathogen. However, little is known about inoculation efficiency or the possible impact of this approach on bacterial infection and colonization. Lopes et al. (2005) compared the efficiency of different inoculation methods, including the pin-prick method here used. That method was superior to other techniques, but similar in efficiency to stem injections. Although pin-pricking may be efficient, it differs from insect inoculation. In fact, Wistrom \& Purcell (2005) tested different host plants for infection by the grapevine strain of $X$. fastidiosa infection, and demonstrated that sharpshooter vectors were more efficient than mechanical inoculation for infecting plants. Furthermore, insects probably inoculate small numbers of $X$. fastidiosa cells when compared to the pin-prick method of mechanical inoculation (Almeida et al., 2005).

Our dose-dependent experiment showed that inoculation of higher concentrations of $X$. fastidiosa resulted in higher infection rates in coffee and citrus. The low inoculation efficiency obtained by the pinpricking method with the lower cell concentrations $\left(10^{3}\right.$ to $10^{5} \mathrm{CFU} \mathrm{mL}{ }^{-1}$ ) was expected. With the most effective and highest bacterial concentrations tested $\left(10^{8}\right.$ or $10^{9} \mathrm{CFU} \mathrm{mL}{ }^{-1}$ ), the number of cells inoculated was around $10^{5}$ or $10^{6}$ cells per $5-\mu \mathrm{L}$ drop of suspension. However, studies in grapevines suggest that few bacterial cells are required for $X$. fastidiosa inoculation by insects, since transmission to healthy plants can take place quickly after a 1-h AAP on a source plant, and only a limited number of cells is expected to colonize the foregut of vectors in such a short time period (Purcell \& Finlay, 1979; Almeida et al., 2005). This substantial difference in the number of cells required for inoculation indicates that differences in the early colonization stage of insect- and mechanically-inoculated plants exist.

The CVC isolate, although colonizing coffee, developed lower bacterial populations in that host plant compared with the CSA isolate. A similar study with almond and grape isolates of $X$. fastidiosa showed that almond isolates colonized grapevines but did not cause disease or reach high populations (Almeida \& Purcell, 2003). These biological differences in host colonization may be used for functional genomic studies aimed at the identification of pathogenicity genes and pathways. It would, for example, be interesting to complement $X$. fastidiosa isolates not able to colonize a host with genes from an isolate capable of doing so to determine its importance on infection development.

Although we tested only one isolate from each host, the results suggest that further investigation is needed to address the pathogenicity and host range of these two $X$. fastidiosa strains. The infection of both citrus and coffee plants by the CVC isolate supports the hypothesis that the citrus strain originated from a 
coffee-colonizing strain. This movement to a new crop may have occurred only once, due to the monophyletic characteristic of the CVC clade in Brazil (Martinati et al., 2005). Such a hypothesis would also explain why the CSA isolate tested could not colonize citrus. Others have previously suggested that CVC originated from the CSA strain; coffee plants with CSA symptoms have for long been observed by growers, but apparently misdiagnosed for nematode or nutritional problems (Paradela Filho et al., 1997; Lima et al., 1998; Li et al., 2001). CVC symptoms were first observed in Brazil in 1987 (Rossetti et al., 1990) and the most severely affected region (Northwestern São Paulo State) was previously occupied by coffee crops (Paradela Filho et al., 1997). The observation of leaf scorch symptoms in coffee plants inoculated with a CVC isolate by $\mathrm{Li}$ et al. (2001) was considered an additional evidence for this hypothesis. However, as already discussed surveys of $X$. fastidiosa in citrus and coffee in Brazil have indicated that these bacteria are genetically distinct. Our results provide biological data corroborating the genetic data, indicating that these strains are distinct.

Additional work with a larger number of $X$. fastidiosa isolates from citrus and coffee is necessary to clarify the biological differences between CVC and CSA strains, as well as the potential for cross-infections in the field. If other isolates of CSA do not infect citrus, it is expected that coffee plantations will not serve as sources of inoculum of the CSA strain of $X$. fastidiosa for citrus groves. But because the CVC strain might be able to infect coffee, plantations may still be sources of the bacterium for citrus. The failure to detect the CVC isolate in coffee plants 12 months after inoculation of the highest dose in our experiment (data not shown) suggests that the bacterium either does not survive for a long time in this host or remains in population levels below the detection threshold for the culturing method $\left(10^{3}\right.$ to $10^{4} \mathrm{CFU} \mathrm{g}^{-1}$ of tissue) (Almeida et al., 2001); alternatively it may not move systemically in coffee as efficiently as in the homologous host. A minimum concentration of $10^{4} \mathrm{CFU}$ $\mathrm{g}^{-1}$ of plant tissue is necessary for $X$. fastidiosa to be acquired and transmitted by an efficient sharpshooter vector on grape (Hill \& Purcell, 1997).

Surveys in coffee plantations would determine the rate of coffee plants naturally infected with the CVC strain, and potentially, the threat of coffee plantations to citrus groves. This question should be addressed because the two crops are often planted side-by-side in affected Brazilian regions and sharpshooter vectors present on citrus are also found on coffee groves (Marucci et al., 1999), allowing the movement of $X$. fastidiosa from one crop to another.

\section{ACKNOWLEDGMENTS}

To Helen Miquelote, Matê Lopes and Fernanda Engels Nascimento for technical assistance, as well as Rosangela Marucci and Terezinha Giustolin for helpful discussions. This research was supported by FAPESP/Brazil and PNP\&D/Café (EMBRAPA/Brazil). The first author had a CAPES/Brazil scholarship and JRSL had a fellowship from Conselho Nacional de Desenvolvimento Científico e Tecnológico (CNPq/Brazil).

\section{REFERENCES}

ALMEIDA, R.P.P.; BLUA, M.J.; LOPES, J.R.S.; PURCELL, A.H. Vector transmission of Xylella fastidiosa: applying fundamental knowledge to generate disease management strategies. Annals of the Entomological Society of America, v.98, p.775-786, 2005.

ALMEIDA, R.P.P.; PEREIRA, E.F.; PURCELL, A.H.; LOPES, J.R.S. Multiplication and movement of a citrus strain of Xylella fastidiosa within sweet orange. Plant Disease, v.85, p.382-386, 2001.

ALMEIDA, R.P.P.; PURCELL, A.H. Biological traits of Xylella fastidiosa strains from grapes and almonds. Applied and Environmental Microbiology, v.69, p.7447-7452, 2003.

COLETTA FILHO, H.D.; TAKITA, M.A.; SOUZA, A.A.; VILDOSO, C.I.A.; MACHADO, M.A. Differentiation of strains of Xylella fastidiosa by a variable number of tandem repeat analysis. Applied and Environmental Microbiology, v.67, p.4091-4095, 2001.

COLLET, D. Modelling binary data. 2 ed. London: Chapman \& Hall, 2002. 369p.

COSTA, P.I.; FRANCO, C.F.; MIRANDA, V.S.; TEIXEIRA, D.C.; HARTUNG, J.S. Strains of Xylella fastidiosa rapidly distinguished by arbitrarily primed-PCR. Current Microbiology, v.40, p.279-282, 2000.

HILL, B.L.; PURCELL, A.H. Multiplication and movement of Xylella fastidiosa within grapevine and four other plants. Phytopathology, v.85, p.1368-1372, 1995.

HILL, B.L.; PURCELL, A.H. Populations of Xylella fastidiosa in plants required for transmission by an efficient vector. Phytopathology, v.87, p.1197-1201, 1997.

HINDE, J.P.; DEMÉTRIO, C.G.B. Overdispersion: models and estimation. Computation Statistics and Data Analysis, v.27, p.151-170, 1998.

LI, W.B.; PRIA, W.D.; TEIXEIRA, D.C.; MIRANDA, V.S.; AYRES, A.J.; FRANCO, C.F.; COSTA, M.G.; HE, C.X.; COSTA, P.I.; HARTUNG, J.S. Coffee leaf scorch caused by a strain of Xylella fastidiosa from citrus. Plant Disease, v.85, p.501-505, 2001.

LI, W.B.; ZHOU, C.H.; PRIA, W.D.; TEIXEIRA, D.C.; MIRANDA, V.S.; PEREIRA, E.O.; AYRES, A.J.; HARTUNG, J.S. Citrus and coffee strains of Xylella fastidiosa induce Pierce's disease in grapevine. Plant Disease, v.86, p.1206-1210, 2002.

LIMA, J.E.O.; MIRANDA, M.P.; HARTUNG, J.S.; COUTINHO, A.; ROBERTO, S.R.; CARLOS, E.F. Coffee leaf scorch bacterium: axenic culture, pathogenicity, and comparison with Xylella fastidiosa of citrus. Plant Disease, v.82, p.94-97, 1998.

LOPES, S.A.; MARCUSSI, S.; TORRES, S.C.Z.; SOUZA, V.; FAGAN, C.; FRANCA, S.C.; FERNANDES, N.G.; LOPES, J.R.S. Weeds as alternative hosts of the citrus, coffee, and plum strains of Xylella fastidiosa in Brazil. Plant Disease, v.87, p.544549, 2003.

LOPES, S.A.; TEIXEIRA, D.C.; FERNANDES, N.G.; AYRES, A.J.; TORRES, S.C.Z.; BARBOSA, J.C. An experimental inoculation system to study citrus-Xylella fastidiosa interactions. Plant Disease, v.89, p.250-254, 2005. 
MAGALHÃES, M.N.; LIMA, A.C.P. Noções de probabilidade e estatística. 4 ed. São Paulo: EDUSP, 2002. 392p.

MARTINATI, J.C.; PACHECO, F.T.H.; DE MIRANDA, V.F.O.; TSAI, S.M. Phylogenetic relationships of Xylella fastidiosa strains based on 16S-23S rDNA sequences. Current Microbiology, v.50, p.190-195, 2005.

MARUCCI, R.C.; CAVICHIOLI, R.R.; ZUCCHI, R.A. Chave para as espécies de cigarrinhas (Hemiptera: Cicadellidae: Cicadellinae) vetoras da clorose variegada dos citros (CVC). Anais da Sociedade Entomológica do Brasil, v.28, p.439-446, 1999.

McCULLAGH, P.; NELDER, J.A. Generalized linear models. 2 ed. London: Chapman \& Hall, 1989. 511p.

MINSAVAGE, G.V.; THOMPSON, C.M.; HOPKINS, D.L.; LEITE, R.M.V.B.C.; STALL, R.E. Development of a polymerase chain reaction protocol for detection of Xylella fastidiosa in plant tissue. Phytopathology, v.84, p.456-461, 1994.

PARADELA FILHO, O.; SUGIMORI, M.H.; RIBEIRO, I.J.A.; GARCIA JUNIOR., A.; BERETTA, M.J.G.; HARAKAWA, R.; MACHADO, M.A.; LARANJEIRA, F.F.; RODRIGUES NETO, J.; BERIAM, L.O.S. Constatação de Xylella fastidiosa em cafeeiro no Brasil. Summa Phytopathologica, v.23, p.4649, 1997

PINTO, F.G.S.; LEITE JUNIOR, R.P. Detecção de Xylella fastidiosa em Coffea spp através da técnica de PCR. Fitopatologia Brasileira, v.24, p.254, 1999.

POOLER, M.; HARTUNG, J.S. Genetic relationship among strains of Xylella fastidiosa based on RAPD-PCR data. Current Microbiology, v.31, p.134-137, 1995.

PURCELL, A.H.; FINLAY, A.H. Evidence for noncirculative transmission of Pierce's disease bacterium by sharpshooter leafhoppers. Phytopathology, v.69, p.393-395, 1979.
PURCELL, A.H.; SAUNDERS, S.R. Fate of Pierce's disease strains of Xylella fastidiosa in common riparian plants in California. Plant Disease, v.83, p.825-830, 1999.

QIN, X.T.; MIRANDA, V.S.; MACHADO, M.A.; LEMOS, E.G.M.; HARTUNG, J.S. An evaluation of the genetic diversity of Xylella fastidiosa isolated from diseased citrus and coffee in Sao Paulo, Brazil. Phytopathology, v.91, p.599-605, 2001.

ROSSETTI, V.; GARNIER, M.; BOVE, J.M.; BERETTA, M.J.G.; TEIXEIRA, A.R.R.; QUAGGIO, J.A.; DE NEGRI, J.D. Presence de bacteries dans le xyleme d'orangers atteints de chlorose variege, une nouvelle maladie des agrumes au Bresil. Comptés Rendus de I' Académie des Sciences. Series III Sciences de la Vie, v.30, p.345-349, 1990.

SANDS, D.C.; SCHROTH, M.N.; HILDEBRAND, D.C. Pseudomonas. In: SCHAAD, N.W. (Ed.) Lab guide for identification of plant pathogenic bacteria. St. Paul: APS Press, 1988. cap.3, p.36-44.

SCHAAD, N.W.; POSTNIKOVA, E.; LACY, G.; FATMI, M.B.; CHANG, C.J. Xylella fastidiosa subspecies: $X$. fastidiosa subsp piercei, subsp nov., $X$. fastidiosa subsp multiplex subsp. nov., and $X$. fastidiosa subsp pauca subsp nov. Systematic and Applied Microbiology, v.27, p.290-300, 2004.

WISTROM, C.; PURCELL, A.H. The fate of Xylella fastidiosa in vineyard weeds and other alternate hosts in California. Plant Disease, v.89, p.994-999, 2005.

Received March 21, 2007

Accepted September 06, 2007 